\title{
連続蒸着法による $\mathrm{ZnS}(\mathrm{Cu}, \mathrm{Mn})$ 薄膜の 作製条件と直流 $\mathrm{EL}$
}

\author{
正員長谷川 秀 雄 (防衛大)
}

\author{
Fabrication and DC Electroluminescent Properties of $\mathrm{ZnS}(\mathrm{Cu}, \mathrm{Mn})$ Thin Films \\ by a Successive Vaccum Deposition Method \\ Hideo Hasegawa, Member (National Defense Academy)
}

\begin{abstract}
To improve the characteristics of a DC thin film EL device, it is required to make a high crystalline phosphor film. In this paper, by using a successive vaccum deposition method, the fabrication conditions of the $\mathrm{ZnS}(\mathrm{Cu}$, $\mathrm{Mn}$ ) thin film which has a high crystallinity are investigated. The $\mathrm{ZnS}(\mathrm{Cu}, \mathrm{Mn}$ ) film is made by successively depositing $\mathrm{ZnS}(1), \mathrm{Mn}, \mathrm{Cu}$ and $\mathrm{ZnS}(2)$ on a glass substrate which was coated with $\mathrm{SnO}_{2}$ electrode. The diffusion of $\mathrm{Mn}, \mathrm{Cu}$ into the host $\mathrm{ZnS}$ is carried out by increasing the substrate temperature to $580^{\circ} \mathrm{C}$ during deposition of the $\mathrm{ZnS}$ ( 2) film. In order to grow the $\mathrm{ZnS}(2)$ film on the $\mathrm{ZnS}(1)$ film epitaxially, a highly oriented $\mathrm{ZnS}$ film as the $\mathrm{ZnS}$ ( 1 ) film is used. After diffusing most of $\mathrm{Mn}, \mathrm{Cu}$ into the $\mathrm{ZnS}(1$ ) film, the $\mathrm{ZnS}(2)$ film is deposited. It is found that the $\mathrm{ZnS}(1)$ film deposited under keeping the substrate at $300^{\circ} \mathrm{C}$ has best crystal orientation along $\langle 111\rangle$ direction. Therefore, the $\mathrm{ZnS}(2)$ film grown along its direction is made and the highly oriented $\mathrm{ZnS}(\mathrm{Cu}, \mathrm{Mn})$ film is obtained. With this $\mathrm{ZnS}(\mathrm{Cu}, \mathrm{Mn})$ film, we have succeded in fabricat. ing the DC thin film EL device which has a luminous efficiency of $0.921 \mathrm{~m} / \mathrm{W}$ at the luminance of $1,300 \mathrm{~cd} / \mathrm{m}^{2}$ and which can continuously drive a luminance of $330 \mathrm{~cd} / \mathrm{m}^{2}$ for 1,100 hours (half-life of 3,400 hours).
\end{abstract}

キーワード：直流 EL， ZnS $(\mathrm{Cu}, \mathrm{Mn})$ 薄膜, X 線回折, PL, 発光効率, 寿命

\section{1.まえがき}

近年，情報処理機器の普及は目覚ましく，その表示装置 として, CRT (陰極線管) に代わる薄くて平板状のもの が要求されるようになり, 各種の薄形平面表示デバイスが 実用化されている。完全固体で自発光形の平面表示デバイ スとして期待されているものに, 薄膜エレクトロルミネッ センス (EL) 素子がある。この素子には，駆動方式によ り $\mathrm{AC}$ 駆動と DC 駆動の 2 種類がある。AC 薄膜 EL 素子 のなかで表示デバイスとして期待されている素子に，猪口 らにより開発された二重絶縁層構造形素子がある(1)。この 素子は高輝度で 1 万時間以上の長寿命の特性を有する。そ の後, この構造を基本にして希土類を発光中心とした多色

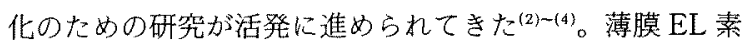
子は，輝度，コントラスト，視野角，ちらつきなどの点で 優れた特徵がある。現在，二重絶緑層構造形素子によるマ トリックス表示パネルが市販され，AC薄膜 $\mathrm{EL}$ 素子は実 用レベルに入っている。なお，この素子は, 駆動電圧が約 $200 \mathrm{~V}$ と高いため, 駆動電源に高酎圧 MOS・IC が使用さ れている。今後, $\mathrm{AC}$ 薄膜 $\mathrm{EL}$ 素子の応用範囲を広げてい
くためには, 駆動電圧の低電圧化, フルカラー化, 高効率 化等を実現していく必要がある(5) ‘6)。

一方, DC 駆動の薄膜 EL 素子は, Thorntonによって 開発されだ7)。この素子は低電圧で発光するという特徴を

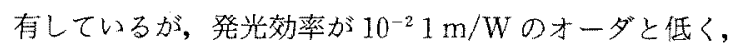
また寿命は数時間と短時間であった ${ }^{(8)}$ 。その後, 発光機構 等の基礎的研究が行われたが(9)-(12), 発光効率, 寿命の改 善は進まなかった。寿命改善の試みとして, Hanak は保 護抵抗層を設けた素子を開発し, 寿命 (半減期) 400 時間

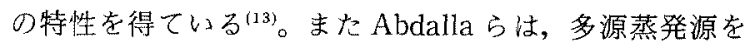
用いて同時蒸着する方法で素子を開発し, 寿命 3,100 時間 の特性を得ているる(14)。しかし，発光効率は $0.11 \mathrm{~m} / \mathrm{W}$ と 低かった ${ }^{(15)}$ 。以上のように，DC 薄膜 $\mathrm{EL}$ 素子は，まだ発 光効率, 寿命が不十分で実用化が進んでいない。一般に, $\mathrm{EL}$ 素子の低電圧駆動化に関しては, DC 薄膜 $\mathrm{EL}$ 素子の 利用が有利であるといわれている。

従来, 橙色発光の $\mathrm{ZnS}(\mathrm{Cu}, \mathrm{Mn})$ 系薄膜の作製法としては, 一源蒸着法が多く採用された(7) (9)(16) -(18)。この方法は，母

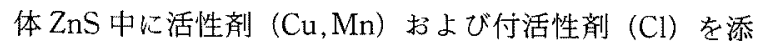
加した材料を真空蒸着する方法であるが, 母体と活性剤が 
分離蒸着されやすく, 蒸着後の熱好理が必要である。更 に，活性剤檂度を制御して膜中に添加することが困難で市 ることなどの問題点があっだ(17)(18)。またそのほかに，気 相反応法(19)，母体膜を蛍光体粉末中に入れて焼成すると 《う方法の埋込み法 ${ }^{(20)(11) \sim(12)}$ おうじ Abdallaら以外の多 源蒸着法(21) などが報告されている。これらの方法も活性 率の制御は容易でない。著者らは, $\mathrm{Cu}, \mathrm{Mn}$ 濃度の制御 を容易にするため, $\mathrm{Mn}, \mathrm{Cu}, \mathrm{ZnS}$ を連続蒸着したのち, $600 \sim 650^{\circ} \mathrm{C}$ で熱処理を行うという方法で $\mathrm{ZnS}(\mathrm{Cu}, \mathrm{Mn})$ 膜 を作製し，比較的長寿命な素子を得ている 後の $\mathrm{ZnS}$ を蒸着するとき, 基板温度を $550 \sim 600^{\circ} \mathrm{C}$ まで上 げて，ZnSの蒸着中に $\mathrm{Mn}$, Cuを母体中に拡散させると いう方法も試みた

DC 薄膜 EL 素子の特性を向上させるためには，まず電 子による発光中心の励起確率を高めることが重要である。 この場合，第一に蛍光体膜の結晶性が高いことが要求され る。前報の連続蒸着法 ${ }^{(22)(23)}$ では, いずれも配向性の低い 膜になっていた。その原因は高温処理にあると考え，本研 究では連続蒸着法を改良して $\mathrm{ZnS}(1), \mathrm{Mn}, \mathrm{Cu}, \mathrm{ZnS}(2)$ を $\mathrm{SnO}_{2}$ 基板上に連続蒸着する方法で $\mathrm{ZnS}(\mathrm{Cu}, \mathrm{Mn})$ 膜の 作製を試みた。その結果, 結晶性の高い $\mathrm{ZnS}(\mathrm{Cu}, \mathrm{Mn})$ 膜 が得られ, 低電圧動作で比較的長寿命特性を有する DC 薄 膜 $\mathrm{EL}$ 素子の作製に成功した。以下にその作製条件と素子 の発光特性について述べる。

\section{2. 素子の作製と実験方法}

図 1 は連続蒸着法を用いて EL 素子を作製するための成 膜手順とEL 素子構造の概略図である。(a)図は各膜の蒸 着順序を，(b)図は完成された $\mathrm{ZnS}(\mathrm{Cu}, \mathrm{Mn})$ 薄膜 $\mathrm{EL}$ 素 子を示している。ここで, 成膜の基板には $\mathrm{SnO}_{2}$ 電極をコ ーティングしたパイレックスガラス板を用いた。(b) 図の素子を作製する場合, $\mathrm{Cu}$ と $\mathrm{Mn}$ 膜を $\mathrm{ZnS}(1)$ 膜と $\mathrm{ZnS}(2)$ 膜の間にサンドイッチ状に蒸着し, 基板温度を高 くして， $\mathrm{Cu} ， \mathrm{Mn}$ を $\mathrm{ZnS}$ 中に㹡散させる手法を用いた。 ここで, $\mathrm{ZnS}(1)$ は最初に蒸着する $\mathrm{ZnS}, \mathrm{Zn}^{\dagger} \cdot 2$ ) は, 最

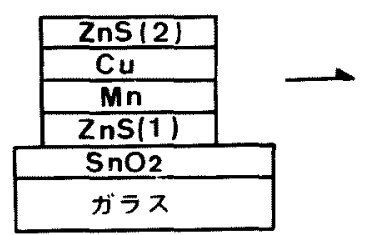

(a)

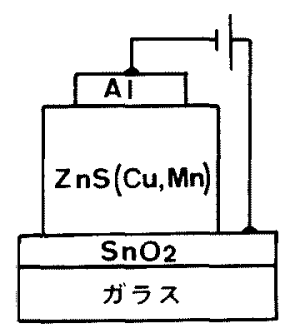

(b)
図 $1 \mathrm{ZnS}(\mathrm{Cu}, \mathrm{Mn})$ 膜の ( a ) 成膜順序と (b) DCEL 素子構造

Fig. 1. (a) Deposition sequence of $\mathrm{ZnS}, \mathrm{Cu}, \mathrm{Mn}$ by the successive vaccum deposition method and (b) structure of $\mathrm{ZnS}(\mathrm{Cu}, \mathrm{Mn})$ thin-film $\mathrm{DC} \mathrm{EL}$ device.
後に蒸着する $\mathrm{ZnS} ゙$ ある。蒸着に用いた各膜材の純度は $99.999 \%$ である

$\mathrm{ZnS}(1)$ 膜の作製には，基板温度を $220 \sim 500^{\circ} \mathrm{C}$ 簕囲 で変化して作製した。ZnS( 1$)$ 膜の厚さは基板と蒸発源と の距離と蒝着材料の仕込量を変えることにより制御した。 蒸発源と基板との間には加熱した二重円筒の囲いを設け， 高温基板への蒸着を容易にした。図 2 はその概略図であ る。 $\mathrm{Mn}, \mathrm{Cu}$ 蒸着する場合, その順序は, 薄い $\mathrm{Cu}$ 膜上 に $\mathrm{nnS}(2)$ 蒸着すると, $\mathrm{ZnS}$ 膜の成長が容易になると いう性質を利用している年。 ボート上に別々に入れ，その全量を蒸発させて膜厚の制御 を行った。なお，基板温度は $250^{\circ} \mathrm{C}$ 一定とした。最後に $\mathrm{ZnS}(2)$ を蒸着した。ところで, ZnSの蒸着は石英製るつ ぼ中に ZnS 粉末を入れ，そのるつぼをモリブデン線ヒー タで加熱するという方法で行った。

$\mathrm{ZnS}(1)$ および $\mathrm{ZnS}(2)$ 膜作製時の蒸発源温度，および 基板温度の温度上昇プログラムは, 予備実験に基づき図 3 のように決定した。このプログラムは, 結晶性の高い $\mathrm{ZnS}(\mathrm{Cu}, \mathrm{Mn})$ 薄膜を作製する手段として, 特に, (i) $\mathrm{ZnS}(1)$ 膜洁晶性の高い膜が蒸着できること, 扔よび (ii) $\mathrm{ZnS}(2)$ 膜が $\mathrm{ZnS}(1)$ 膜上にエピタキシャル的に成膜 するように，大多数の $\mathrm{Mn} ， \mathrm{Cu}$ を $\mathrm{ZnS}(1)$ 膜中に拡散さ せたのち, $\mathrm{ZnS}(2)$ が蒸着できることを考慮して組み立て た。ここで、実線は蒸発源温度, 破線は基板温度である。 な⿰七, 予備実験から $\mathrm{ZnS}$ 素材を蒸着する際, 蒸発源温度 毎分 $3^{\circ} \mathrm{C}$ 割合で上昇させ $910^{\circ} \mathrm{C}$ までげると，その素 材の約 95\%が蒸発することがわかった。ここでは，毎分 $3^{\circ} \mathrm{C}$ を最低温度上昇速度とした。

曲線 ( a ) 打よび曲線 ( b ) は，それでれ $\mathrm{ZnS}(1)$ および $\mathrm{ZnS}(2)$ )蒸発源温度上昇方法である。 $500^{\circ} \mathrm{C}$ 一定で 1 時 間保持して $\mathrm{ZnS}$ 粉末中の不純物ガスを排除したのち, $\mathrm{ZnS}(1)$ については毎分 $4^{\circ} \mathrm{C}, \mathrm{ZnS}(2)$ については每分

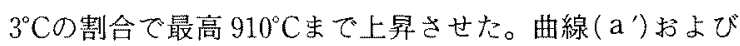
曲線( $\left.\mathrm{b}^{\prime}\right)$ は，それそれれ $\mathrm{ZnS}(1)$ および $\mathrm{ZnS}(2)$ の基板温

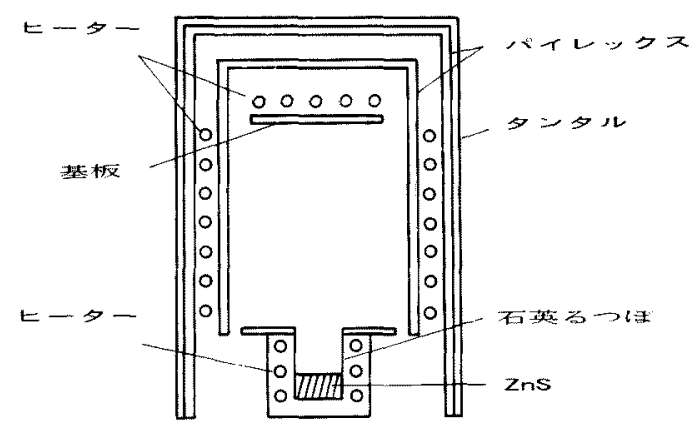

図 $2 \mathrm{ZnS}(1)$ 扝よび $\mathrm{ZnS}(2)$ 膜の作製に用いた 真空槽内の蒸着装置の概略図

Fig. 2. Schematic diagram of deposition apparatus in vaccum chamber used for making $\mathrm{ZnS}_{\mathrm{n}}(1)$ or $\mathrm{ZnS}(2)$ films. 


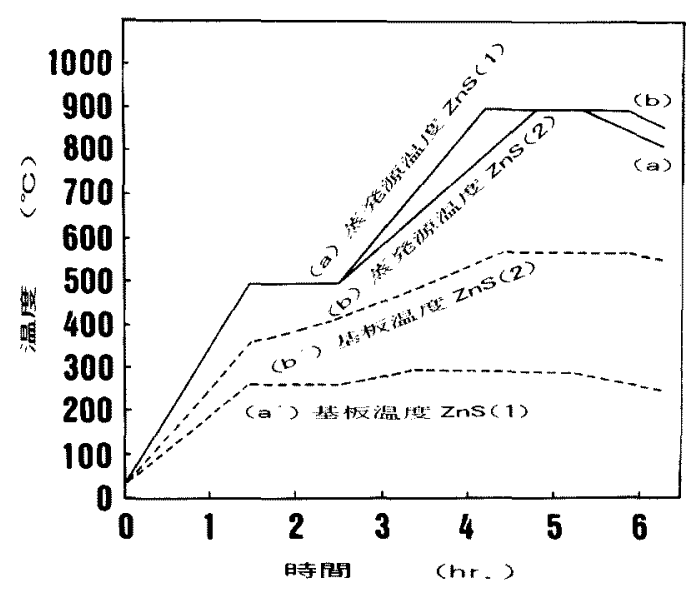

図 $3 \mathrm{ZnS}(1)$ および $\mathrm{ZnS}(2)$ 膜を作製するための 蒸発源温度と基板温度の温度上昇プログラム

Fig. 3. Temperature program of evaporation source temperature (solid lines) and substrate temperature (dashed lines) for making $\mathrm{ZnS}(1)$ or $\mathrm{ZnS}(2)$ films.

度上昇方法である。 $\mathrm{ZnS}$ 素材は $700^{\circ} \mathrm{C}$ 前後の温度から蒸発 し始める。そこで, ZnS(1)については，蒸発源温度がそ の温度に達したとき，所定の基板温度，例えば $300^{\circ} \mathrm{C}$ （220～500 Cの)範囲）になるように調節した。 $\mathrm{ZnS}(2)$ に ついては，その温度までに $\mathrm{Cu}, \mathrm{Mn}$ が $\mathrm{ZnS}(1)$ 膜中に拡

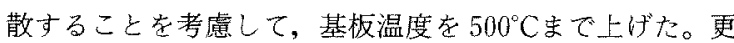
に, $\mathrm{ZnS}(2)$ 膜中にも $\mathrm{Cu}, \mathrm{Mn}$ が拡散するように最高 $580^{\circ} \mathrm{C}$ ま怆た。なお，蒸発源温度についてもこの点を 考虑して，その上昇速度を遅くした。〔曲線( b ) 〕。蒸着終 了後，基板温度を毎分 $0.3 \sim 0.5^{\circ} \mathrm{C}$ 割合で徐冷した。最 後に, $\mathrm{Al}$ を蒸着して対向電極とし, 図 $1(\mathrm{~b})$ ) EL 素子を 得た。

以上の各膜の作製は，通常の真空排気装置を使用して， すべて3〜 4 × $10^{-4} \mathrm{~Pa}$ の真空中で行った。 $\mathrm{ZnS}(1)$ 膜およ $ひ ゙ \mathrm{Mn}, \mathrm{Cu}, \mathrm{ZnS}(2)$ 膜まで蒸着した膜の結晶性の評価 は，X線回折像抢上び電子顥微鏡観察加ら行った。 $\mathrm{Cu}$, $\mathrm{Mn}$ の拡散の度合はホトルミネッセンス (PL) 強度から 見積もった。以上の実駼では島津製 XD-DIS 形 X 線回折 装置, 日本電子製 JSM-25 SII 形走查形電子顕微鏡および 島津製 RF-5000 形蛍光分光光度計を使用した。更に EL 素子の特性評価として, 電流一電圧特性, 輝度一電圧特性, 発光効率および寿命を調べた。これらの実験には,グラフ テック製WX 4401 形 $X-Y$ レコーダ，トプコン製 BM-3 形輝度計および YHP 製 $214 \mathrm{~B}$ 形パルスジェネレー夕を使 用した。

\section{3. 実験結果と考察}

\section{〈3・1〉 $\mathrm{ZnS}(1)$ および $\mathrm{ZnS}(\mathrm{Cu}, \mathrm{Mn})$ 膜のX $\mathrm{X}$ 線回折}

図 4 は, $\mathrm{ZnS}(1)$ 膜蒸着時の基板温度と(111) 面 X 線 回折強度との関係を示している。ここで用いた $\mathrm{ZnS}(1)$ 膜の膜厚は3.0 3.3 $\mu \mathrm{m}$ である。図中の回折強度は, 基

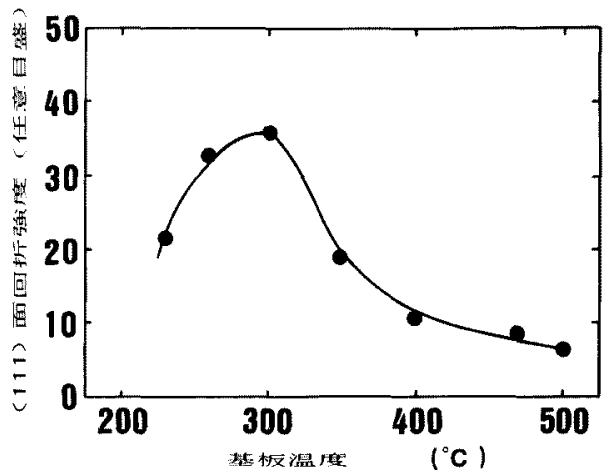

図 $4 \mathrm{ZnS}(1)$ 膜の (1 111$)$ 面 $\mathrm{X}$ 線回折強度の 基板温度依存性

Fig. 4. Dependence of $\left(\begin{array}{llll}1 & 1 & 1\end{array}\right) \mathrm{X}$-ray diffraction intensity on the substrate temperature during deposition of $\operatorname{ZnS}(1)$ films.

板温度 $300^{\circ} \mathrm{C}$ 膜が最も強く，それより温度を上げても強 度は增加していない。なお，これらの膜には，後述するよ うに（111）面以外からもかずかな回折が現われていた。 以上の結果, 基板温度 $300^{\circ} \mathrm{C}$ のきの膜が最も結晶性の良 い膜になることがわかった。一般に，基板温度を高くする ほど，結晶性の高い膜になるといわれているが(24)(25)，本 実験ではそのような結果海得られなかった。ところで, 蒸 発源温度の上昇速度を遅くするほど結晶性の高い $\mathrm{ZnS}(1)$ 膜が得られるが， $4^{\circ} \mathrm{C} / \mathrm{min}$ と $3^{\circ} \mathrm{C} / \mathrm{min}$ とではほとえど変 化は見られなかった。しかし， 2 倍の $8^{\circ} \mathrm{C} / \mathrm{min}$ にすると，基 板温度 $300^{\circ} \mathrm{C}$ の場合で回折強度は約 $60 \%$ に低下した。

図 5 は, 基板温度 $300^{\circ} \mathrm{C}$ O $\mathrm{ZnS}(1)$ 膜上に $\mathrm{Mn}, \mathrm{Cu}$, $\mathrm{ZnS}(2)$ 膜を蒸着する過程の X 線回折特性である。図中 (A) は ZnS (1) 膜の膜厚が $2 \mu \mathrm{m}$ ，（B）は $3 \mu \mathrm{m}$ の場合の 特性である。図中，曲線( a ) は $\mathrm{ZnS}(1)$ 膜の特性， $\left(\mathrm{b}_{1}\right)$ は $\mathrm{ZnS}(1)$ 膜上に $\mathrm{Mn}, \mathrm{Cu}$ を蒸着したのち $500^{\circ} \mathrm{C}$ まて熱 処理した膜の特性である。ただしこの段階では ZnS (2) は蒸着されていない。 $\left(\mathrm{b}_{2}\right)$ は $\mathrm{Mn}, \mathrm{Cu}$ を蒸着せず $\mathrm{ZnS}(1)$ 膜を $500^{\circ} \mathrm{C}$ まで熱処理した膜の特性，(c) は $\mathrm{ZnS}(1)$ 膜上 に Mn， $\mathrm{Cu}, \mathrm{ZnS}(2)$ を蒸着したときの特性である。この

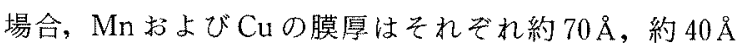
であり， $\mathrm{ZnS}(2) 0 そ れ は 1 \mu \mathrm{m}$ である。なお，各曲線に は, 電極に用いた $\mathrm{SnO}_{2}$ による弱い回折が現われていたが, 本曲線では省略している。

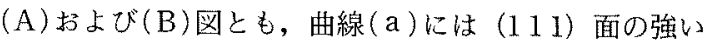
回折と（222）面のごく弱い回折が現われている。(1 11 ) 面の回折強度は曲線 $(\mathrm{a}),\left(\mathrm{b}_{1}\right),\left(\mathrm{b}_{2}\right)$ 抢よび $(\mathrm{c})$ の順に増 加しているが，(222) 面の回折はほとんど変化していな い。な抢，(A)図の曲線(c)には，前述の 2 面以外に非常 に弱い (200)，(220)，(311）面の回折が現われてい る。この膜は, 〈 1111 軸以外飞複数の弱い配向軸をもっ た膜になっていることがわかる。この変化は，基板温度が 高いため蒸着された原子が移動しやすくなり，多方向に膜 が成長したものと考えられる。(B)図の曲線(a)の（111) 


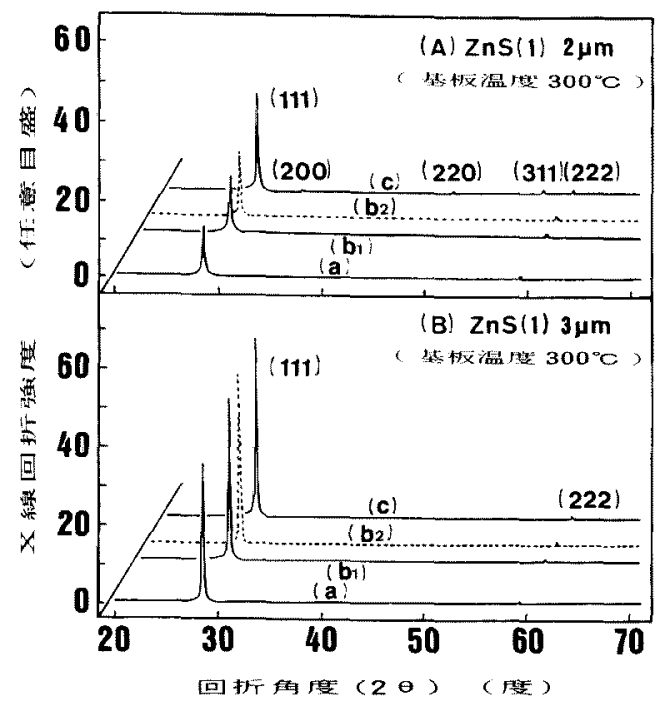

(a) : $\mathrm{ZnS}(1)$ 膜, $\left(\mathrm{b}_{1}\right): \mathrm{ZnS}(1)$ 膜上に $\mathrm{Mn}, \mathrm{Cu}$ 萎着後, $500^{\circ} \mathrm{C}$ をで加熱した膜， $\left(\mathrm{b}_{2}\right): \mathrm{ZnS}(1)$ 膜を $500^{\circ} \mathrm{C}$ まで熱処理し

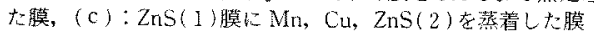

図 5 基板温度 $300^{\circ} \mathrm{C} O \mathrm{ZnS}(1)$ 膜上に $\mathrm{Mn}, \mathrm{Cu}$, $\mathrm{ZnS}(2)$ 膜を蒸着する過程のX 線回折図形

Fig. 5. X-ray diffraction patterns. (a) patterns of $\mathrm{ZnS}$ (1) films deposited with the substrate kept at $300^{\circ} \mathrm{C},\left(\mathrm{b}_{1}\right)$ patterns of films deposited $\mathrm{Mn}, \mathrm{Cu}$ on the $\mathrm{ZnS}(1)$ films and then annealed at $500^{\circ} \mathrm{C},\left(\mathrm{b}_{2}\right)$ patterns of $\mathrm{ZnS}(1)$ films annealed at $500^{\circ} \mathrm{C}$ without depositing $\mathrm{Mn}$, and (c) patterens of films deposit ed Mn, Cu, ZnS(2) on the ZnS( 1 ) films.

面回折の半值幅角 $(\Delta 2 \theta)$ は $0.19^{\circ}$ であったが, 曲線 $(\mathrm{C})$ のそれは $0.16^{\circ}$ にった。

以上の結果, 基板温度 $300^{\circ} \mathrm{C} \mathrm{ZnS}(1)$ 膜上に $\mathrm{Mn}$, $\mathrm{Cu}, \mathrm{ZnS}(2)$ を蒸着していくと，(111) 面の回折強度が 増加した膜になるが， $\mathrm{ZnS}(1)$ 膜が薄いと〈111〉軸以外 にも複数の弱い配向軸をもった膜になること，一方，膜厚 を $3 \mu \mathrm{m}$ と厚〈すると $\mathrm{ZnS}(2)$ 膜は $\mathrm{ZnS}(1)$ 膜の〈1 11$\rangle$ 軸の配向に沿って成膜され, 配向度の高い柱状多結晶構造 粒子の $\mathrm{ZnS}(\mathrm{Cu}, \mathrm{Mn})$ 膜になることがわかった。

図 6 は， $\mathrm{ZnS}(1)$ 膜に基板温度 $500^{\circ} \mathrm{C}$ 膜を用いた場合 の図 5 と同様な過程を調べた特性である。図中特に注目さ れる点は，(A)，(B)図とも曲線(a)には，既に (200)， (220)，(311)面の回折が現れていること，および(A)図 の曲線 $\left(b_{1}\right)$ では $(200)$ 面の回折が強くなっているのに対 して, 曲線 $\left(\mathrm{b}_{2}\right)$ で斿号の面の回折は変わっていない点であ る。前者は前述の高温基板の影響であり, 後者の変化は, $\mathrm{Mn}, \mathrm{Cu}$ が $\mathrm{ZnS}$ (1) 膜中に拡散したことによる影響と考 えられる。そして, (A) 図の曲線 ( $\mathrm{c}$ ) は, 曲線 $\left(\mathrm{b}_{1}\right)$ 膜の影 響を受けて (220) 面の回折がかなり強くなっている。三 上らは, HT-CVD 法で生成した ZnS膜は, Mnの拡散に より結晶棈造が立方晶系から六方晶系へ変わると報告して いるが(26)，そのような結果什得られなかった。 以上の結果,

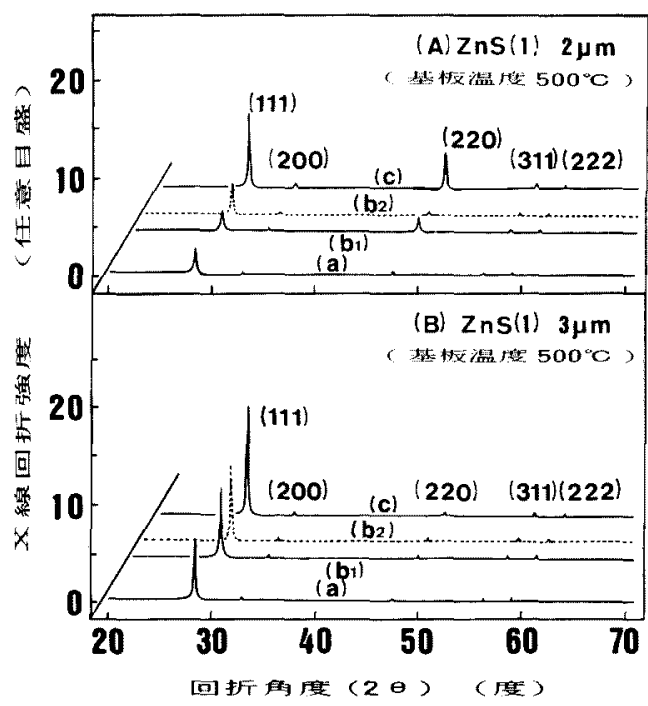

(a)，( $\left(b_{1}\right) ，\left(b_{2}\right) ，(c)$ は基板温度 $500^{\circ} \mathrm{C} @ \mathrm{ZnS}(1)$ 膜を用いた以 外, 他门条件は図 5 と同し

图 6 基板温度 $500^{\circ} \mathrm{C}$ の $\mathrm{ZnS}(1)$ 膜上に $\mathrm{Mn}, \mathrm{Cu}$, $\mathrm{ZnS}(2)$ 膜を蒸着する過程のX 線回折図形

Fig. $6 . \quad \mathrm{X}$-ray diffraction patterns. The film prepa. ration conditions of $(a),\left(b_{1}\right),\left(b_{2}\right)$ and $(c)$ are the same as those of Fig. 5 except using $\operatorname{ZnS}(1)$ films deposited with the substrate kept at $500^{\circ} \mathrm{C}$.

(i) 基板温度 $500^{\circ} \mathrm{C}$ O $\mathrm{ZnS}(1)$ 膜は〈111 軸以外飞 も複数の配向軸をもった膜になること。

（ii）その $\mathrm{ZnS}(1)$ 膜が薄いと $\mathrm{Mn}, \mathrm{Cu} の$ 拡散の影響 を受けて〈1 10〉軸方向にも強く配向した膜にな り，配向性が悪くなること。

などがわかった。図 5, 図 6 から, $\mathrm{ZnS}(1)$ 膜の配向性を 維持しながら次の $\mathrm{ZnS}(2)$ 膜が成膜するためには，Mn， Cuの挔散と高温基板の影響を受けないように, 配向度が 高くて厚い $\mathrm{ZnS}(1)$ 膜を用いることが重要であることが わかった。なお，複数の配向軸をもった $\mathrm{ZnS}(1)$ 膜は基 板温度 $400^{\circ} \mathrm{C}$ 付近の膜加ら観察された。

〈3・2〉 $\mathrm{ZnS}(1)$ および $\mathrm{ZnS}(\mathrm{Cu}, \mathrm{Mn})$ 膜の電子顕微鏡 写真図 7(a), (b) \& $\mathrm{ZnS}(1)$ 膜表面乱よび $\mathrm{ZnS}(1)$ 膜上に $\mathrm{Mn}, \mathrm{Cu}, \mathrm{ZnS}(2)$ を蒸着した膜表面の走查電子顕 微鏡写真である。基板温度 $300^{\circ} \mathrm{C} の \mathrm{ZnS}(1)$ 膜(図 7(a) (1)」では小さな粒径が密集しているが， $500^{\circ} \mathrm{C} の \mathrm{ZnS}$ (1)膜[図7(b)-(1)]で注粒径は大きいが，粒径内の山 凸がやや滑らかであることが観察される。ZnS(1)膜上に $\mathrm{Mn}, \mathrm{Cu}, \mathrm{ZnS}(2)$ 蒸着した膜は, 基板温度 $300^{\circ} \mathrm{C} の$ $\mathrm{ZnS}(1)$ 膜の場合[図 7(a)-(2)], 粒径が大きくなり, 結晶性が改善されていることがわかる。一方 $500^{\circ} \mathrm{C} の$ $\mathrm{ZnS}(1)$ 膜の場合(図 7(b)-(2)],粒径の大きさはあまり 変わらず，その表面が丸みを帯びているのが観察される。

〈3・3〉 $\mathbf{Z n S}(\mathbf{C u}, \mathbf{M n})$ 膜の PL特性 図 8 は $\mathrm{ZnS}(1)$ ， $\mathrm{Mn}, \mathrm{Cu}$ 膜を $500^{\circ} \mathrm{C}$ まで熱処理した膜，およびその膜上に 
更にZnS ( 2)を蒸着した膜について, Mn のピーク波長 $580 \mathrm{~nm}$ の $\mathrm{PL}$ 強度と $\mathrm{ZnS}(1)$ 膜蒸着時の基板温度との関 係を示している。励起波長には, $\mathrm{ZnS}$ の吸収端波長より 短い $330 \mathrm{~nm}$ の波長を使用した。この波長の ZnS に対す る吸収係数は $1 \times 10^{4} \mathrm{~mm}^{-1}$ 程度 ${ }^{(27)}$ であり,この紫外線は 膜のごく表面層を励起していることになる。ここで, 紫外 線を基板側 $\left(\mathrm{SnO}_{2}\right.$ 電極側）に照射した場合が曲線 ( a ), 膜表面側に照射した場合が曲線 ( b ) である。また, 破線は $\mathrm{ZnS}(1), \mathrm{Mn}, \mathrm{Cu}$ 膜を $500^{\circ} \mathrm{C}$ まて熱処理した膜の特性, 実線は $\mathrm{ZnS}(1), \mathrm{Mn}, \mathrm{Cu}, \mathrm{ZnS}(2)$ 膜の特性である。 破線の曲線 ( a ) では, 基板温度 $260 \sim 500^{\circ} \mathrm{C}$ の゙゙の膜も $\mathrm{PL}$ が現われている。これより $500^{\circ} \mathrm{C}$ 熱処理で $\mathrm{Mn}$ が基 板側まで拡散されていることがわかる。また, PL 強度は 基板温度 $300^{\circ} \mathrm{C}$ の膜がいちばん強く, その基板温度依存性 は, 図 4 の $\mathrm{ZnS}(1)$ 膜の X 線回折強度特性とほぼ同じ傾 向を示している。基板温度 $300^{\circ} \mathrm{C}$ の $\mathrm{nS}(1)$ 膜は, PL 強 度が高いことから配向性の良さだけでなく, 格子久陥や格 子ひずみの少ない膜になっていることが考えられる。破線 の曲線 (b) は曲線 ( a ) より低い值を示しているが，その低 い原因法, 膜表面側の Mn 濃度が高いための濃度消光現 象(28)によるものと推定される。これより多くの $\mathrm{Mn}$ が $\mathrm{ZnS}$ ( 1) 膜中に入ったと考えられる。実線の曲線( a), (b) は, 破線の曲線 ( a ), ( b ) と同様な傾向を示している が, PL 強度はそれぞれ低い。この低下は, ZnS ( 2)膜中 に Mn が拡散したことを示していると考えられる。

なお， $\mathrm{Cu}$ の拡散は $\mathrm{ZnS}(1)$ 膜蒸着時の基板温度 $400^{\circ} \mathrm{C}$ 前後の温度から起こることを, $\mathrm{Cu}$ のピーク波長 $450 \mathrm{~nm}$

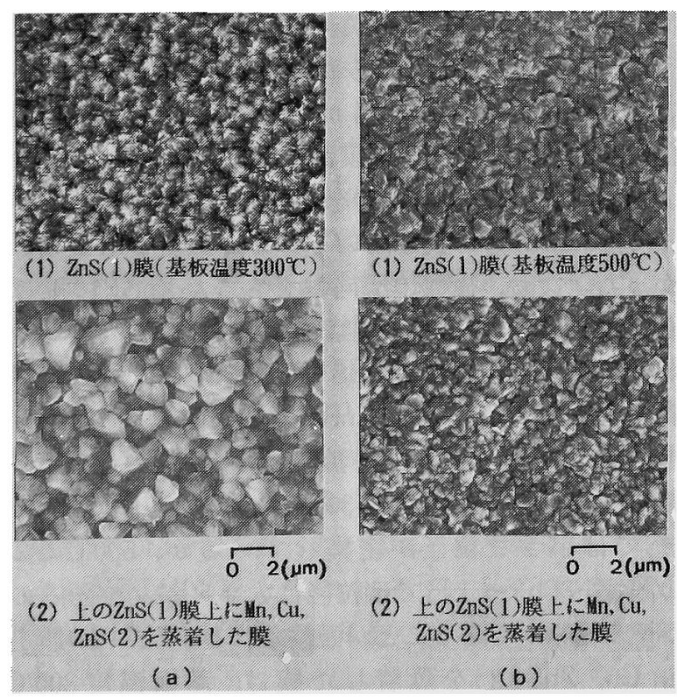

図 7 基板温度の異なる二つの $\mathrm{ZnS}(1)$ 膜と その膜上に $\mathrm{Mn}, \mathrm{Cu}, \mathrm{ZnS}(2)$ を蒸着した 膜の走査電子顕微鏡写真

Fig. 7. Scanning electron microphotographs of ((a) 1, (b ) 1) ZnS ( 1 ) films prepared at different substrate temperatures and $\{(\mathrm{a}) 2$, (b)2) films deposied $\mathrm{Mn}, \mathrm{Cu}, \mathrm{ZnS}(2)$ on the $\mathrm{ZnS}$ ( 1 ) films.
および $520 \mathrm{~nm}$ の PL 測定から明らかにしている(29)。しか し，十分に拡散させるためには，500 $\mathrm{C}$ 以上の基板温度が 必要で, 今回もこの温度に設定した。更に, $\mathrm{ZnS}(2)$ 膜中 にも Cu が拡散していることを前述と同様な PL 測定から 確認している。以上, PL の測定から, ZnS(2)膜を蒸着 する以前に $\mathrm{Mn}, \mathrm{Cu} の$ 多くが $\mathrm{ZnS}(1)$ 膜中に拡散してい ること, 更に $\mathrm{ZnS}(2)$ 膜中にもそれらが拡散しているこ とを示唆しているデータが得られた。

〈3.4〉 発光特性 $\mathrm{ZnS}(1), \mathrm{Mn}, \mathrm{Cu}$ 膜を $500^{\circ} \mathrm{C}$ ま で熱処理した膜でも発光を示していたが, やや明るさと発 光の均一性が不足していた。均一で明るい発光を示すため

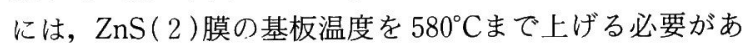
った。この素子は, $\mathrm{SnO}_{2}$ 電極に対して, ぞちらの極性に 電圧を印加しても発光するが，その電極にプラス電圧を印 加したほうが明るく発光した。これは, $\mathrm{PL}$ 強度が $\mathrm{SnO}_{2}$ 電極側のほうが高いからで, 発光領域は, プラス電極に近 い側の $\mathrm{ZnS}(\mathrm{Cu}, \mathrm{Mn})$ 膜内に形成される。 $\mathrm{ZnS}(\mathrm{Cu}, \mathrm{Mn})$ 素子は, 最初に大きな電流が流机るが, 次第に電流が下が るとともに発光を開始するというフォーミング現象が起こ る。このとき, 発光層が形成される。著者らは, このフォ ーミングを加熱下で行うと, 発光時に流れる電流が大幅に 減少することを見いだした ${ }^{(22)(30)}$ 。以後の発光特性は, $\mathrm{SnO}_{2}$ 電極にプラス電圧を印加した場合で, 加熱下フォー ミング処理を行っている。

図 9 は, $\mathrm{ZnS}(1)$ 膜上に $\mathrm{Mn}, \mathrm{Cu}, \mathrm{ZnS}(2)$ まで蒸着し た $\mathrm{ZnS}(\mathrm{Cu}, \mathrm{Mn})$ 薄膜 $\mathrm{EL}$ 素子の輝度-印加電圧特性であ る。実線は基板温度 $300^{\circ} \mathrm{C} の \mathrm{ZnS}(1)$ 膜を用いた素子の特

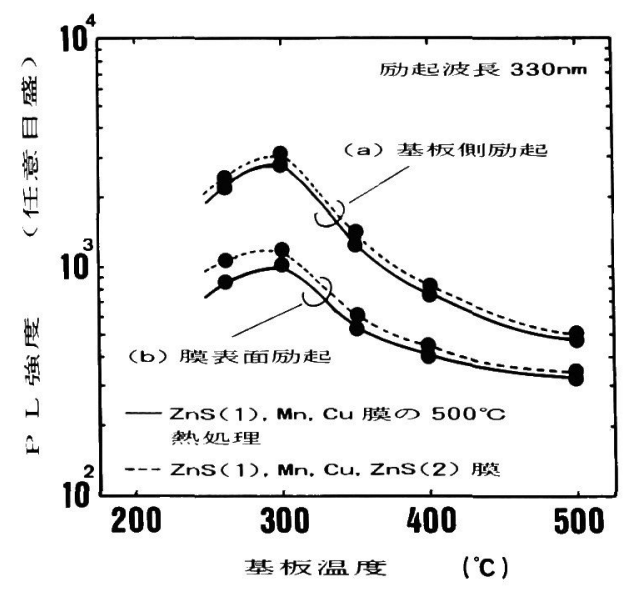

図 $8 \mathrm{ZnS}(1), \mathrm{Mn}, \mathrm{Cu}$ 膜を熱処理した膜 および $\mathrm{ZnS}(1), \mathrm{Mn}, \mathrm{Cu}, \mathrm{ZnS}(2)$ 膜の ピーク波長 $580 \mathrm{~nm}$ の PL 強度の $\mathrm{ZnS}(1)$ 膜蒸着時の基板温度依存性

Fig. 8. Dependence of PL intensity at $580 \mathrm{~nm}$ for $\mathrm{ZnS}(1), \mathrm{Mn}, \mathrm{Cu}$ films annealed at $500^{\circ} \mathrm{C}$ (dashed lines) and $\mathrm{ZnS}(1), \mathrm{Mn}, \mathrm{Cu}, \mathrm{ZnS}(2)$ films (solid lines) on the substrate temperature during deposition of $\mathrm{ZnS}(1)$ films. PL intensity was measured with excitation by $330 \mathrm{~nm}$ light (a) through the substrate and ( $b$ ) through the outer surface. 
性, 破線は基板温度 $500^{\circ} \mathrm{C}$ 妍 (1) 膜を用いた素子の特 性である。愿さ $2 \mu \mathrm{m}$ の $\mathrm{ZnS}(1)$ 膜を用いた素子は，いず れの基板温度の膜とも発光開始電圧は低いが，1,000 cd/ $\mathrm{m}^{2}$ 付近から輝度の飽和傾向が見られる。これらの膜は， 比較的高いPL 值を示していたが, 多くの電流が流れたこ とにより輝度飽和が早かったものと考えられる。素子に流 れる電流は主として膜中の $\mathrm{Cu}$ 濃度によって決まる(18)(19)。 一方, 厚さ $3 \mu \mathrm{m}$ で基板温度 $300^{\circ} \mathrm{C} の \mathrm{ZnS}(1)$ 膜を用いた 素子は, $42 \mathrm{~V}$ で煇度 $3,050 \mathrm{~cd} / \mathrm{m}^{2}$ の高い值を示している。

図 10 は, 図 9 の素子の発光効率-輝度特性である。厚さ $3 \mu \mathrm{m}$ の $\mathrm{ZnS}(1)$ 膜を用いた素子は，基板温度 $300^{\circ} \mathrm{C}$ 膜 の場合で最大 $0.92 \mathrm{~lm} / \mathrm{W}$ (輝度 $1,300 \mathrm{~cd} / \mathrm{m}^{2}$ ), 基板温度 $500^{\circ} \mathrm{C}$ 膜の場合で最大 $0.60 \mathrm{~lm} / \mathrm{W}$ の值になる。一方, 厚さ $2 \mu \mathrm{m} の \mathrm{ZnS}(1)$ 膜の場合は, 前述の輝度飽和々電流 が多かったことによりやや低い発光効率值になっている。 以上の結果, 今回の連続蒸着法では, 高輝度において比較 的高い発光効率の膜を得ることができた。

〈3.5〉 寿命特性 図 11 は, 図 90 厚さ3 $3 \mu \mathrm{m}$ の基板 温度 $300^{\circ} \mathrm{C}$ の $\mathrm{nS}(1)$ 膜を用いた素子 (A) と基板温度 $500^{\circ} \mathrm{C}$ ～ZnS（1）膜を用いた素子(B)のパルス駆動による 寿命特性である。素子はシリコーン系樹脂で被覆した。繰 返し周波数は $1 \mathrm{kHz}$ ，パルス占有率は $1 \%$ である。榇子 (A) と素子（B）の初期輝度を同じくするため，それぞれに

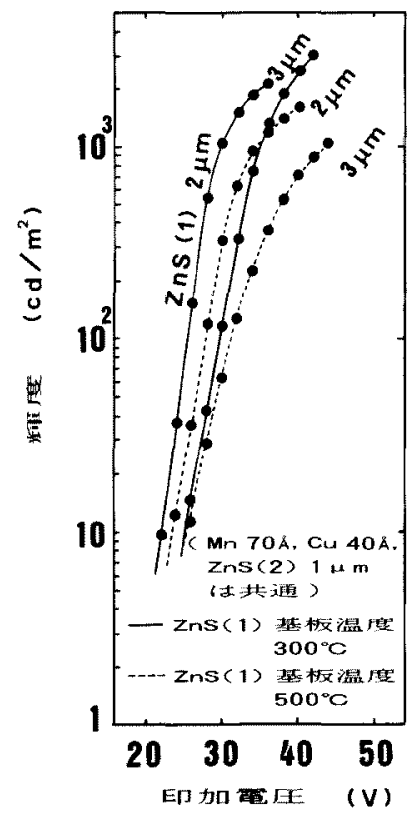

図 $9 \mathrm{ZnS}(\mathrm{Cu}, \mathrm{Mn})$ 薄膜 DCEL 素子の 輝度一印加電圧特性

Fig. 9. Luminance-applied voltage characteristics for $\mathrm{ZnS}(\mathrm{Cu}, \mathrm{Mn})$ thin-film DCEL devices with ZnS (1) films deposited on the substrate kept at $300^{\circ} \mathrm{C}$ (solid lines) and $500^{\circ} \mathrm{C}$ (dashed lines). The deposition conditions of $\mathrm{Mn}, \mathrm{Cu}, \mathrm{ZnS}(2)$ in each device are the same.

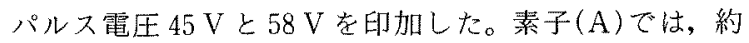
200 時間まで輝度が増加し, 以後, 約 1,100 時間まで輝度 $330 \mathrm{~cd} / \mathrm{m}^{2}$ を維持している。この素子の半減期は 3,400 時 間になる。一方, 素子 (B)の半隇期は 500 時間程度にな る。両素子とも輝度低下後, 膜にわずかなひざ割れが観察 された。特に素子(B)の方のひび割れが大きかった。ひび 割れの原因の一つとして, 蒸着後, 膜の徐冷速度が早かつ たことが考えられる。今後，ひび割れ防止を検討していき たい。なお，図 9 の厚さ $2 \mu \mathrm{m} の 2$ 種類の膜は，いずれも 坌化が早く, 半減期は素子(B)の $1 / 2$ 程度であった。

表 1 は, これまでに報告された $\mathrm{ZnS}(\mathrm{Cu}, \mathrm{Mn})$ 系薄膜 DCEL 素子の特性と本実験結果との比較である。最大輝 度は本素子が最も高い $3,050 \mathrm{~cd} / \mathrm{m}^{2}$ の值を示している。発 光効率注前報の連続蒸着法のほうがわずかに高いが，その

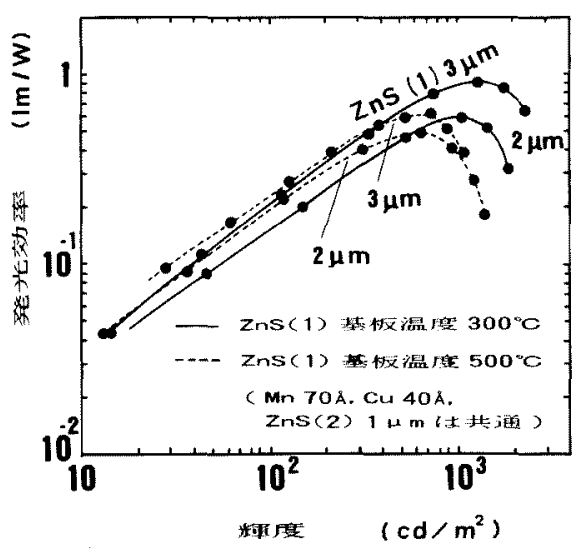

図 $10 \mathrm{ZnS}(\mathrm{Cu}, \mathrm{Mn})$ 薄膜 DCEL 素子の 発光効率-輝度特性

Fig. 10. Relationship between luminous efficiency and luminance for $\mathrm{ZnS}(\mathrm{Cu}, \mathrm{Mn})$ thin-film DCEL device in Fig. 9.

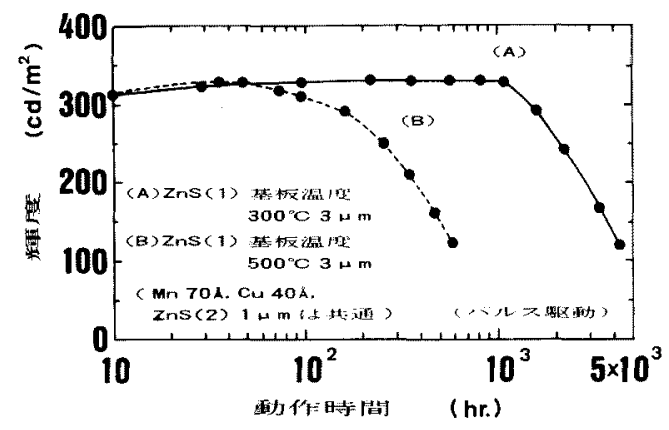

図 11 パルス駆動による $\mathrm{ZnS}(\mathrm{Cu}, \mathrm{Mn})$ 薄膜 DCEL 素子の寿命特性

Fig. 11. Maintenance characteristics of $\mathrm{ZnS}(\mathrm{Cu}, \mathrm{Mn})$ thin-film DCEL devices operated with DC pulse excitation. (A) $\mathrm{ZnS}(1) 3 \mu \mathrm{m}$ (substrate temp. $300^{\circ} \mathrm{C}$ ), $\mathrm{Mn}$ $70 \AA, \mathrm{Cu} 40 \AA, \mathrm{ZnS}(2) 1 \mu \mathrm{m}$; (B) $\mathrm{ZnS}(1) 3 \mu \mathrm{m}$ (substrate temp. $500^{\circ} \mathrm{C}$ ), Mn $70 \AA, \mathrm{Cu} 40 \AA, \mathrm{ZnS}(2)$ $1 \mu \mathrm{m}$. 
表 $1 \mathrm{ZnS}(\mathrm{Cu}, \mathrm{Mn})$ 系薄膜 DCEL 素子の特性の比較 Table 1. Comparision of properties of reported DCEL thin-film devices in $\mathrm{ZnS}(\mathrm{Cu}, \mathrm{Mn})$ systems and our results.

\begin{tabular}{|c|c|c|c|}
\hline 製作万法 & $\begin{array}{l}\text { 策大頙度 } \\
\left(\mathrm{cd} / \mathrm{m}^{2}\right)\end{array}$ & $\begin{array}{l}\text { 発壮効率 } \\
(\mathrm{m} / \mathrm{W})\end{array}$ & $\begin{array}{c}\text { 寿命 } \\
\text { (蛙減期) }\end{array}$ \\
\hline 一源蒸着法 ${ }^{(8)}$ & $\begin{array}{c}2,070 \\
(80 \mathrm{~V})^{* 1}\end{array}$ & $\begin{array}{c}0.05 \\
\left(34 \mathrm{~cd} / \mathrm{m}^{2}\right)^{* 2}\end{array}$ & 数㭙闎 \\
\hline 気柏叹店法(19) & $\begin{array}{c}340 \\
(60 \mathrm{~V})\end{array}$ & 0.08 & 報告なし \\
\hline 埋込2 法 & $\begin{array}{l}1,700 \\
(40 \mathrm{~V})\end{array}$ & 0.1 & 数時間 \\
\hline 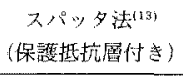 & $\begin{array}{c}2,650 \\
(\text { パンス } 230 \mathrm{~V})\end{array}$ & $\begin{array}{c}0.4 \\
\left(70 \mathrm{~cd} / \mathrm{m}^{2}\right)\end{array}$ & $\begin{array}{c}400 \text { 時間 } \\
\left(50 \mathrm{~cd} / \mathrm{m}^{2}\right)^{* 3}\end{array}$ \\
\hline 多源蒸着法(11)(15) & $\begin{array}{c}340 \\
(25 \mathrm{~V})\end{array}$ & 0.1 & $\begin{array}{c}3,100 \text { 時閫 } \\
\left(70 \mathrm{~cd} / \mathrm{m}^{2}\right)\end{array}$ \\
\hline $\begin{array}{l}\text { 前報の)連続 } \\
\text { 蒸㺕法 }\end{array}$ & $\begin{array}{l}1,400 \\
(42 \mathrm{~V})\end{array}$ & $\begin{array}{c}1.2 \\
\left(340 \mathrm{~cd} / \mathrm{m}^{2}\right)\end{array}$ & $\begin{array}{l}500 \text { 時間後 } \\
\text { 約 } 11 \% \text { 減* } \\
\left(120 \mathrm{~cd} / \mathrm{m}^{2}\right)\end{array}$ \\
\hline 本報告 & $\begin{array}{l}3,050 \\
\langle 42 \mathrm{~V}\rangle\end{array}$ & $\begin{array}{c}0.92 \\
\left(1,300 \mathrm{~cd} / \mathrm{m}^{2}\right)\end{array}$ & $\begin{array}{c}3,400 \text { 時間 } \\
\left(320 \mathrm{~cd} / \mathrm{m}^{2}\right)\end{array}$ \\
\hline
\end{tabular}

* 1：最大輝度時の印加電生

* 2: 発光効率時の輝度

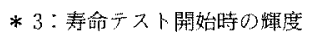

* 4: 寿命テス卜は 500 時間まて

ときの輝度は本素子のほうが高い。寿命時間は Abdalla らの值 ${ }^{(14)}$ と同程度であるが，本素子は高い輝度に扔いて テストを行っている。また, Abdallaらの結果は，1,000 時間後には初期輝度の $54 \%$ に低下して抢り，初期の輝度 低下が大きい。粉末形 $\mathrm{EL}$ 素子は, 粉末の粒径が大きいほ ど，長寿命な素子になることが知られている(5)。薄膜の場 合, 基板に対して柱状に成長した多結晶粒子の粒径が大き いことが必要と考无られる。本方法の膜は, 図70写真か らも粒径が大きい。その結果, 本素子が高い輝度で比較的 長寿命な特性を示したものと思われる。

本素子をディスプレイの観点から検討すると, 輝度は $100 \sim 150 \mathrm{~cd} / \mathrm{m}^{2}$ あればよく(31)/(32), 寿命は実用化に, 最低 3,000 時間は必要といわれている(33)。市販されている $\mathrm{AC}$ 粉末形 $\mathrm{EL}$ 素子の寿命はほほ漂この程度である(5)(34)。本素子 は，必要輝度より高い值でその時間以上の寿命を示してい る。発光効率は, $\mathrm{AC}$ 薄膜形 $\mathrm{EL}$ 素子で 1 4 $\mathrm{lm} / \mathrm{W} の も$ のが実用化されている(5)(6)。本素子はほぼこの值に近い。 以上の輝度, 寿命扔よび発光効率に関して, 本素子はほぼ 実用化条件を満たしている。更に，駆動電圧の低電圧化に 対しては, 駆動電源のIC 化を容易にするため, $50 \mathrm{~V}$ 以下 で発光することが望ましいといわれている(35)。この点に 関しても本素子はその要求を満たしている。しかし, 将来 のディスプレイの高容量化のためには，な扔いっそうの発 光効率の向上と低電圧化が望まれる。

\section{4. 結論}

本研究では, $\mathrm{ZnS}(1), \mathrm{Mn}, \mathrm{Cu}, \mathrm{ZnS}(2)$ の連続蒸着 により, $\mathrm{ZnS}(\mathrm{Cu}, \mathrm{Mn})$ 膜の作製を試みた。最初に, 結晶
性の高い $\mathrm{ZnS}(1)$ 膜の作製条件を見いだした。次にそ の膜用いることにより， Mn， Cuの ZnS 中八の拡散と 同時に, $\mathrm{ZnS}(2)$ が $\mathrm{ZnS}(1)$ 膜の配向性を維持しながら成 膜できる条件を明らかにした。その結果, 結晶性の高い $\mathrm{ZnS}(\mathrm{Cu}, \mathrm{Mn})$ 膜が得られ, 高効率で比較的長寿命な DC 薄膜 $\mathrm{EL}$ 素子の作製に成功した。笑駼結果を要約すると以 下のようになる。

(1) $\mathrm{ZnS}(1)$ 膜を蒸着する実験から，基板温度 $300^{\circ} \mathrm{C}$ で蒸発源温度を徐々に上昇 $\left(4^{\circ} \mathrm{C} / \mathrm{min}\right)$ させて蒸着するこ とにより，〈1 1 1 〉軸方向に最も強〈配向した，(1 1 1 ) 面 回折の半值幅角 $(\Delta 2 \theta)$ が $0.19^{\circ}$ の膜が得られた。

（2）結晶性の良い基板温度 $300^{\circ} \mathrm{C}$, 厚さ $3 \mu \mathrm{m} \sigma$ $\mathrm{ZnS}$ (1) 膜上に $\mathrm{Mn}, \mathrm{Cu}$ を蒸着し, 多くの $\mathrm{Mn}, \mathrm{Cu}$ を $\mathrm{ZnS}(1)$ 膜中に拡散させたのち $\mathrm{ZnS}(2)$ を蒸着すると, $\mathrm{ZnS}(1)$ 膜の配向軸に沿って $\mathrm{ZnS}(2)$ が成膜され, $\mathrm{ZnS}(1)$ 膜と同様に結晶性の良い $\mathrm{ZnS}(\mathrm{Cu}, \mathrm{Mn})$ 膜を得ることが できたこの膜の(1 111$)$ 面回折の半值幅角 $(\Delta 2 \theta)$ は $0.16^{\circ}$ であった。一方, 結晶性の低い $\mathrm{ZnS}(1)$ 膜を用いると, $\mathrm{ZnS}(2)$ 蒸着時の基板温度の影響で〈1 111$\rangle$ 軸以外に複数 の弱い配向軸をもった膜や $\mathrm{Mn}, \mathrm{Cu}$ の拡散の影響を受け て〈1 I 0〉軸方向にも強く配向した膜になった。

（3）基板温度 $300^{\circ} \mathrm{C}$ で厚さ $3 \mu \mathrm{m}$ の $\mathrm{ZnS}(1)$ 膜上に, 約 $70 \AA$ O $\mathrm{Mn}$, 約 $40 \AA の \mathrm{Cu}, 1 \mu \mathrm{m} \sigma \mathrm{ZnS}(2)$ を蒸着し た $\mathrm{ZnS}(\mathrm{Cu}, \mathrm{Mn})$ 膜において, 輝度 $1,300 \mathrm{~cd} / \mathrm{m}^{2}$ で発光効 率 $0.92 \mathrm{~lm} / \mathrm{W}$ の高い值を得た。

（4）（3）の素子において，連続動作で高い輝度の330 $\mathrm{cd} / \mathrm{m}^{2}$ を約 1,100 時間まで維持した特性（半隇期 3,400 時 間）を示した。この特性は従来の報告より良い。これは， $\mathrm{ZnS}(\mathrm{Cu}, \mathrm{Mn})$ 膜の結晶性が高いことによるものと考えら れる。

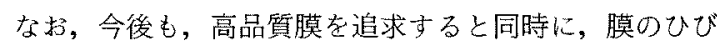
割れ対策も明らかにして，更に長寿命な素子を完成させて いきたい。

最後に, 本研究を進めるに際し, 本学電気工学教空主任 室岡義広教授にはこの間終始, 御䭒篤なる御指導と激励を 賜りました。ここに記して感謝の意を表します。

(平成 6 年 3 月 15 日受付, 同 6 年 8 月 18 日再受付)

\section{文献}

(1) T. Inoguchi, M. Takeda, Y. Kakihara \& M. Yoshida: "Stable High-Brightness Thin-Film Electroluminescent Panels", SID Int. Symp. Dig. Tech. p. 84 (1974)

(2) T. Suyama, N. Sawara, K. Okamoto \& Y. Hamakawa "Multi color Electroluminescent Device", Japan. J. Appl. Phys, 21, 383 (1982)

(3) H. Kobayashi, S. Tanaka, V. Shanker, M. Shiiki, T Kunou, J. Mita \& H. Sasakura: "Multicolor Electroluminescent ZnS Thin Film Doped with Rare Earth Fluorides", Phys. State Sol., $88,713(1985)$

(4) H. Ohnishi, K. Yamamoto \& Y Katayama: "Improved Efficiency of Green Color ACTFEL Divices Grown by RFSputtering", Conf. Record 1985 Int. Display Res. Conf., IEEE, NeW York, p. 159 (1985)

（5）電気学会：「最近の電子ディスプレイデバイスの研究動向」, 電 気学会技報(II)，No. 205，17（昭 60) 
（6）猪口敏夫：エレクトロルミネセントディスプレイ,p. 95 (平 3) 産業図書

(7) W. A. Thornton: "Electroluminescent Thin Films", J. Appl. Phys., 30, 123 (1959)

(8) W.A. Thornton: "dc Electroluminescence in Zinc Sulfide Films", ibid., 33, 3045 (1962)

(9) P. Goldberg \& J. W. Nicerson: "DC Electroluminescence of ZnS", ibid., 34, 1601 (1963)

(10) N. A. Valasence \& A. N. Gersell: "On the Mechanism of DC Electroluminescence in $\mathrm{pCu}_{x} \mathrm{~S}-\mathrm{nZnS}: \mathrm{Mn}, \mathrm{Cu}, \mathrm{Cl}$ Film Structures", Phys. State Sol., 26, k77 (1968)

(11) W. Riemer and R. E. W. Lake: "Preparation, Forming, and Aging of Electroluminescen $\mathrm{ZnS}: \mathrm{Mn}, \mathrm{Cu}, \mathrm{Cl}$ Films", J. Electrochem. Soc., 117, 1293 (1970)

(12) J. M. Plumb: "DC Characteristics of Electroluminescent Evaporated $\mathrm{ZnS}$ : Mn, Cu, Cl Films", Japan. J. Appl. Phys., 10, 326 (1971)

(13) J. J. Hanak: "Electroluminescence in $\mathrm{ZnS}: \mathrm{Mn}, \mathrm{Cu}, \mathrm{rf}-$ Sputtered Films", ibid., Suppl. 2, Pt. 1, 809 (1974)

(14) M. I. Abdalla, J. A. Thomas, A. Brenac \& J. P. Noblanc: "Performance of DC EL Coevaporated ZnS: Mn, Cu Low Voltage Devices", IEEE Electron Devices, ED-28, 694 (1981)

(15) M. I. Abdalla \& J.A. Thomas: "LOW VOLTAGE D.C ELECTROLOMINESCENCE IN ZNS (MN, CU) THIN FIL MS", Proc. SID, 19/3, 91 (1978)

(16) W. Uchida : "Electroluminescence of $\mathrm{ZnS}$ : $\mathrm{Mn}, \mathrm{Cu}, \mathrm{Cl}$ Film s", Japan, J. Appl. Phys., 7, 378 (1968)

(17) T. Miyata, S. Nakagawa, H. Hirayama, H. Hasegawa \& M Korenaga: "dc Electroluminescence and Related Properties in Evaporated Thin Films of $\mathrm{ZnS}(\mathrm{Cu}, \mathrm{Mn}, \mathrm{Cl})$ ", ibid., 9, 615 (1970)

（18）長谷川秀雄・中川修三・高木邦雄：「ZnS 蒸着 $\mathrm{EL}$ 膜の蒸着条件 と膜の諸特性」, 防衛大理工学研報, 17, 243 (昭 54)

(19) D. A. Cusano: in Luminescence of Organic and In-organac Materials (ed.by H.P. Kallman and G. M. Spuch), p. 494 (1962) John Wiley and Sons

(20) W. A. Thornton: "PREPARATION AND PROPERTIES OF ELECTROLUMINESCENT FILMS", Electrochemical $A b-$ stract (Pittsburgh Meeting), 12, 59 (1963)

(21) N. A. Valasenco \& Iu. A. Porkov: "Study of the electroluminescence sublimed $\mathrm{ZnS}$ : Mn phospher", Optics \& Spectros., 8, 39 (1960)

(22) H. Hasegawa \& S. Nakagawa: "DC Electroluminescence in $\mathrm{ZnS}(\mathrm{Cu}, \mathrm{Mn})$ Prepared by a Successive Vacuum Deposition
Method", Proc. SID, 28, 27 (1987)

（23）長谷川秀雄：「蒸着拡散 $\mathrm{ZnS}(\mathrm{Cu}, \mathrm{Mn})$ 薄膜の直流 EL 特性」, 第 33 回真空に関する講演会, 29 B-6 (平 4)

(24) T. J. Coutts (ed) : ACTIVE AND PASSIVE THIN FILM DEVICES, p. 518 (1978) Academic Press

（25）沢木 司：真空蒸着, p. 174（昭 40）日刊工業新聞社

(26) A. Mikami, K. Terada, K. Okibayashi, K. Tanaka, M. Yoshida \& S. Nakajima: "Chemical vapor depodition of $\mathrm{ZnS}$ : Mn electroluminescent films in a low-pressure halogen transport system", J. Cryst. Growth, 110, 381 (1991)

(27) H. W. Leverenz: An introduction of Luminescent solid, p. 161 (1951) John Wily \& Sons

（28）蛍光体同学会編：営光体ハンドブック，D.78（昭 62）オーム社

（29）長谷川秀雄：「 $\mathrm{ZnS}(\mathrm{Cu}, \mathrm{Mn})$ 薄膜直流 $\mathrm{EL}$ 素子の作製」，第 51 回応用物理学会学術講演会, $9 \mathrm{aG} 2$ (平 3 )

(30) 長谷川秀雄：「ZnS (Cu, Mn $)$ 薄膜直流 EL 素子の>ォーミン グと発光」，応用物理， 59,653 (平 2)

（31）テレビジョン学会編：画像ディスブレイ，p.193（昭 50）コロ ナ社

(32）畑田豊彦：「ディスプレイに要求される機能」, 照明学誌, 73, 724 (平元)

(33) A. Vecht: "D.C. ELECTROLUMINESCENCE IN ZINC SUL PHIDE AND RELATED COMPOUNDS", J. Luminescence, 7 213 (1973)

（34）松原 修：「エレクトロルミネッセンスパネル」, 照明学誌 73,729 (平元)

（35） 浜川圭弘・山本敏雄・深尾隆三：「チューナブルカラーEL 素 子小, テレビジョン学誌, 40, 998 (1986)

長谷川 秀 雄 (正員) 1940 年 9 月 3 日生。1963 年 3 月東京電

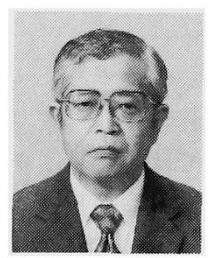
機大学工学部電子工学科卒業。現在, 防衛大学 校電気工学科講師。工学博士。主として, 薄膜 EL 素子に関する研究に従事。応用物理学会, SID 学会, 日本結晶成長学会, 日本真空協会会 員。 